\title{
Evaluating the Training, Responsibilities, and Practices of P\&T Committee Members and Nonmember Contributors
}

\author{
Ryan Rodriguez, PharmD, BCPS; Brett J. Kelly, BSPharm, MS; and Mary Moody, BSPharm
}

\begin{abstract}
BACKGROUND: Pharmacy and therapeutics (P\&T) committees are responsible for managing drug formularies in numerous health care settings. Although pharmacy practice and health care organizations provide general recommendations of responsibilities and skills for members and nonmember contributors of P\&T committees, the study investigators hypothesized that there is diversity in the training, responsibilities, and practices of these members and contributors.
\end{abstract}

OBJECTIVE: To describe the training, responsibilities, and practices of members and nonmember contributors of P\&T committees in a variety of health care settings, using an online survey.

METHODS: In December 2015, an online survey was delivered to clinicians who were considered likely to be involved in P\&T committee service from hospitals ranked by U.S. News \& World Report and a convenience sample of clinicians practicing in managed care settings. The survey instrument was designed to assess various domains and perceptions of P\&T committee processes.

RESULTS: Sixty-nine respondents representing various health care delivery settings in the United States were eligible for and completed the survey. The majority of the respondents were pharmacists (94.2\%), and $72.5 \%$ of the respondents were P\&T committee members. The remainder of the respondents were nonmember P\&T committee contributors. Approximately $60 \%$ of the respondents had served in P\&T committee roles for $\geq 10$ years. Specialized postgraduate training incorporating literature evaluation and formulary management was possessed by $21.7 \%$ and $17.4 \%$ of the respondents, respectively; however, most of the respondents received on-the-job training. Approximately half of the respondents were responsible for preparation of P\&T committee documents, and $58 \%$ reported that nonmember contributors typically write and prepare these documents. Skill in literature evaluation was the most important criterion in selecting authors of P\&T committee documents, while $10.1 \%$ of the respondents indicated that their committees did not use any criteria for author selection. When authoring documents, primary literature was routinely consulted by $89.5 \%$ of the respondents. Most of the respondents $(84.1 \%)$ used an organizationspecific document template, while $5.8 \%$ of the respondents indicated that they prepared documents with no defined process. The most highly ranked factor that could have a perceived beneficial effect on P\&T committee functions were guidelines on the authoring and reviewing of P\&T committee documents.

CONCLUSIONS: The survey of P\&T committee members and nonmember contributors used in this study identified current training, responsibilities, and practices that can inform recommendations for standards in these domains. Findings suggest opportunities for improvement in achieving best practice recommendations to ensure evidence-based decision making by P\&T committees.

J Manag Care Spec Pharm. 2017;23(8):868-74

Copyright $\odot 2017$, Academy of Managed Care Pharmacy. All rights reserved.

\section{What is already known about this subject}

The practice of evidence-based medicine requires practitioners to be proficient in the searching and evaluation of medical literature and the application of that literature to clinical practice.

Pharmacy and therapeutics (P\&T) committees, which apply evidence-based principles to formulary management, have few guidance documents that indicate recommended best practices and standards for training of committee members.

\section{What this study adds}

Literature evaluation skills were most highly valued in work related to P\&T committee tasks among experienced committee members and nonmember contributors in a variety of health care settings. More than half of P\&T committee documents were prepared by nonmember contributors, and a minority of respondents indicated that their institutions had no defined process for selecting authors or preparing these documents.

Less than one quarter of respondents possessed specialized training in literature evaluation or formulary management, and guidance regarding the production of P\&T committee documents was highly desired.

$\mathrm{P}$ harmacy and therapeutics (P\&T) committees are responsible for managing drug formulary systems in various inpatient and outpatient health care organizations, including acute care hospitals and managed care organizations. ${ }^{1,2}$ P\&T committees are composed of health care professionals who participate in the medication use process and serve in an advisory capacity to their organizations' medical and administrative staff in all drug-related matters. Goals of a P\&T committee are to optimize policies, communication, and education related to medication use and to manage a drug formulary to provide the most appropriate and cost-effective care to unique patient populations. Because responsibilities of P\&T committees vary based on the specific populations and health care delivery models they serve, the required training, responsibilities, and practices of those involved in P\&T committees can vary widely from one setting to another. ${ }^{1}$

Formulary management tasks undertaken by P\&T committees are numerous and have been generally delineated by 
various professional organizations., ${ }^{1,2}$ Policy statements have outlined recommendations for formulary management in health care settings ranging from national formularies to unique patient populations (e.g., patients in nursing facilities)., ${ }^{1,3-6}$ Inclusion of P\&T committees in formulary management is a requirement by Medicare Part D. ${ }^{7}$ Recommendations that are common among these policy statements include the development of a standardized formulary management process, use of expert panels (i.e., subcommittees), written presentation of information using a standardized format, and above all, a formalized evidence-based evaluation process., ${ }^{1,2,5,6,8}$ Given their numerous responsibilities, P\&T committees may transfer some work from committee members (i.e., those appointed to the committee) to representatives from appropriate specialties (i.e., contributors). ${ }^{2}$

Evidence-based medicine requires practitioners to be proficient in the searching and evaluation of medical literature and the application of that literature to clinical practice. ${ }^{1}$ However, problems in the application of evidence-based principles in P\&T committee decision making have been documented. For example, a team of members and chairs of multiple U.S. formulary committees observed wide disparities in the quality of debate and discussion related to formulary decisions, which were perceived as "subjective, unsystematic, and incomplete." This perception is shared by the Delfini Group, whose purpose is to help clinicians learn and apply the concepts, methods, processes, skills, and tools of evidence- and value-based clinical decisions. ${ }^{8}$ The Delfini Group also noted a lack of proficiency in literature evaluation among learners of evidencebased practice, regardless of their health care discipline, tenure of professional practice, and practice setting, and has recommended that P\&T committees rely on contributors who are most skilled in critical appraisal of medical literature. ${ }^{10}$

Despite these observations and recommendations, P\&T committee and formulary management position statements often lack statements regarding the requisite training of members and contributors in order to ensure evidence-based decision making. Furthermore, little systematic research has been performed to quantify the extent of member and contributor training. According to statements from the American Society of Health-Systems Pharmacists (ASHP), P\&T committee responsibility often falls on pharmacists (particularly drug information specialists), whose training uniquely prepares them to lead in the preparation and presentation of P\&T committee documents. ${ }^{1,8,10,11}$ However, full deliberation of P\&T committees relies on all members and contributors, some of whom may not possess such specialized training.

All members of a P\&T committee should receive training in the critical analysis of medical literature. ${ }^{8}$ Considering the highly dynamic and person-powered decision-making processes that often result from unstructured P\&T committee debates, the Delifini Group highlights the need for critical analysis because of the importance of maintaining the focus of discussions on evidence. ${ }^{11}$ Consequently, the group recommends that training in critical literature appraisal be implemented in orientation and continued training meetings.

Given the lack of requisite training for P\&T committee members and contributors and the variety of settings in which P\&T committee functions occur, the authors of this study hypothesized that there is diversity in training, responsibilities, and practices of P\&T committee members and contributors. Therefore, the objective of this study was to perform a descriptive analysis of these domains among clinicians serving P\&T committees in a variety of health care settings, using an online survey.

\section{Methods}

In December 2015, an online survey was developed by the authors to assess the training, responsibilities, and practices of members and contributors to P\&T committees. The survey was reviewed by professional colleagues experienced in various inpatient and managed care formulary management settings and revised accordingly. The research was approved by a local investigational review board.

Survey delivery was via e-mail to clinicians who were determined to likely be involved in P\&T committees. Potential recipients were identified by various means. To systematically identify recipients from a publicly available list of inpatient settings, hospitals were identified using the U.S. News \& World Report's ranking of the nation's best hospitals. ${ }^{12}$ Within each specialty, the top $5 \%$ of ranked hospitals or all hospitals that received numerical rankings were used as a convenience sample. Rankings were accessed in August 2015. Clinicians holding titles at these institutions who were deemed likely to be involved in P\&T committees (e.g., medical director, director of pharmacy, drug information staff, and medication use policy) were identified by reviewing directories of providers and medical and pharmacy training programs at each institution. Those providing care exclusively in ophthalmology, rehabilitation, and pediatric settings were excluded.

Survey respondents from managed care settings were identified via contact lists from numerous commercial payers provided by an independent health care consulting firm. Clinicians serving Medicaid populations were identified from publicly available information about each state's Medicaid P\&T committee. One target P\&T committee contributor was contacted per entity, and if they did not hold the assessed P\&T committee responsibilities, they were requested to forward the survey to the appropriate person who did.

In addition to demographic information related to practice setting and patient population served, the survey instrument was designed to assess various domains of P\&T committee 
functions outlined by previously mentioned policy statements. These functions included access to resources for, and preparation of, P\&T committee documents, meeting preparation strategies, training in P\&T committee functions and formulary management, standardized policies for production and review of P\&T committee documents, and pharmacoeconomic assessments. Factors believed to influence the selection of authors for P\&T committee documents were assessed. In addition, we surveyed respondents' satisfaction with their institutions' P\&T committee processes and factors that could potentially improve these processes. Since the survey was intended to be descriptive only, no hypothesis testing was performed.

\section{Results}

\section{Characteristics of P\&T Committees and Contributors}

The survey targeted 1,035 unique email addresses and was successfully delivered to 836 recipients. Overall, 69 (8.25\%) respondents were eligible for and completed the survey, 2 of which were not included in the initial address list. All respondents' institutions managed their own P\&T committee processes. The majority of respondents (94.2\%) were pharmacists, along with one each of physician, nurse, and contracting professional.

Among respondents, $71 \%$ held membership positions in their P\&T committees, while the remainder served in contributor roles. The greatest proportion were voting committee members (30.4\%); $18.8 \%$ were nonvoting members; and the remainder occupied positions of chair or co-chair (13.0\%) and secretary (8.7\%). Some respondents (27.5\%) were contributors, providing service as requested by their committees, but were not formal members. One respondent moderated committee meetings.

Health care market types served by respondent P\&T committees varied, with the highest proportion (47.8\%) serving a combination of 2 or more assessed categories of health care delivery, followed by hospital (18.8\%), commercial payer (14.5\%), Medicaid (13.0\%), federal (4.3\%), and Medicare Part D settings (1.4\%). Among 13 respondents serving on inpatient hospital P\&T committees, the majority (61.5\%) practiced in an academic teaching setting, while $30.8 \%$ and $7.7 \%$, respectively, practiced in community teaching and community nonteaching settings. Nearly all of these hospitals (92.3\%) had a capacity of more than 500 beds; the remainder $(n=1)$ had a capacity of 150-300 beds. Among respondents serving on managed care P\&T committees ( $n=56)$, the largest proportion had multistate coverage (46.4\%), followed by single state (25\%), local (16.1\%), and national (12.5\%) coverage.

Duration of service in formulary management roles was predominantly greater than 10 years $(59.4 \%) ; 29.0 \%$ of the respondents had practice experience from 5 to 10 years; and $11.5 \%$ had practiced for 5 years or less. Almost all respondents (95.7\%) received no additional compensation for their P\&T

\begin{tabular}{l|rr}
\hline \multicolumn{1}{|c|}{ TABLE 1 } & $\begin{array}{l}\text { The Most Important Criteria for } \\
\text { Selecting Authors of P\&T Committee } \\
\text { Documents (N=69) }\end{array}$ \\
\hline Criteria & \multicolumn{2}{c}{$\mathbf{n}(\%)$} \\
\hline Expertise in literature evaluation & 31 & $(44.9)$ \\
\hline Expertise in therapeutic area of document & 12 & $(17.4)$ \\
\hline Authorship is required for P\&T committee appointment & 9 & $(13.0)$ \\
\hline No defined selection criteria & 7 & $(10.1)$ \\
\hline Possession of sufficient time for authorship & 4 & $(5.8)$ \\
\hline Expertise in medical writing & 3 & $(4.3)$ \\
\hline Practice in health care discipline related to document & 3 & $(4.3)$ \\
\hline PET $=$ pharmacy and therapeutics. & & \\
\hline
\end{tabular}

service. Those who received financial compensation specifically for service to P\&T committees served in settings of commercial payers, Medicaid, and settings that were combinations of 2 or more health care delivery categories ( $\mathrm{n}=1$ for each); all were pharmacists.

\section{Processes for Document Preparation}

Overall, $94.8 \%$ of respondents reported that pharmacists were the most common health care professionals to author P\&T committee documents; among these, a majority were nonmember contributors (58.0\%). Members of P\&T committees authored documents in $42 \%$ of respondents' organizations, while $42 \%$ relied on pharmacy benefit managers or outside consulting services to perform this work. Institutions that outsourced document production included those of 2 or more health care delivery types (41.4\%), commercial payers (27.6\%), Medicaid (27.6\%), and Medicare Part D plans (3.4\%). No respondents serving inpatient or federal P\&T committees outsourced authorship.

Authorship of P\&T committee documents was a routine responsibility of $55.1 \%$ of respondents. Among them, authorship of a typical class review required 8-24 hours for a majority (56.8\%) of these contributors (1 hour to $<8$ hours, $24.3 \%$; 24 hours to $<48$ hours, $8.1 \%$; 48 hours to $<96$ hours, $10.8 \%$ ). All respondents provided information on the most important critera in selecting authors of P\&T committee documents (Table 1), of which the most frequently selected was literature evaluation skills (44.9\%). There were no defined selection criteria in $10.1 \%$ of respondents' organizations. To guide document preparation, the committees of the majority of respondents (84.1\%) used formalized protocols, policies, or templates that were specific to their organizations; $34.8 \%$ followed published guidelines on formulary systems and/or P\&T committees; $14.5 \%$ followed a personal practice; and $5.8 \%$ had no defined process.

Pharmacoeconomic assessments were included in P\&T committee documents at $71.0 \%$ of respondents' institutions. Most frequently, these assessments were performed by 


\begin{tabular}{|c|c|}
\hline $\begin{array}{c}\text { TABLE } 2 \text { Types of Resources Cc } \\
\text { Authors of P\&T Comm } \\
\text { Documents ( } N=38)\end{array}$ & \\
\hline Resource $^{\mathrm{a}}$ & n (\%) \\
\hline Primary literature & $34 \quad(89.5)$ \\
\hline Package inserts & $30 \quad(78.9)$ \\
\hline Electronic tertiary resources & $28 \quad(73.7)$ \\
\hline Marketing information provided by manufacturers & $24 \quad(63.2)$ \\
\hline Secondary resources & $22 \quad(57.9)$ \\
\hline Print tertiary resources & $12 \quad(31.6)$ \\
\hline Internet & $5 \quad(13.2)$ \\
\hline Other & $4 \quad(10.5)$ \\
\hline
\end{tabular}

pharmacists (67.3\%), while only $8.2 \%$ used a pharmacoeconomist. Authors of the documents, regardless of qualifications, were expected to perform this assessment in $20.4 \%$ of the respondents' organizations. Other strategies for pharmacoeconomic assessment relied on administrative pharmacy managers and guidelines from contractors ( $\mathrm{n}=1$ for each).

The informational resources used by respondents during authorship of P\&T committee documents varied (Table 2). A variety of reputable data sources (e.g., subscription medical information services or publicly funded databases) were used, with $13.2 \%$ of the respondents consulting non-peer-reviewed public internet sources (e.g., Google). Other resources provided by respondents included clinical dossiers and health technology assessment documents prepared by government bodies. The proportions of authors who did not have access to more than 10, 5-10, 2-5, and 0-1 of the previously mentioned resources were $7.9 \%, 15.8 \%, 21.1 \%$, and $55.3 \%$, respectively.

\section{Preparation for, and Execution of, P\&T Committee Meetings}

According to respondents, annual meeting frequency of P\&T committees was most often 4 times annually $(47.8 \%)$, followed by $5-12$ times (40.6\%), 12 or more times (8.7\%), and $1-3$ times (2.9\%). The duration of P\&T committee meetings was 2 hours or less in 58\% of the respondents' organizations. Meetings lasted 2-4, hours, 4-8 hours, and more than 8 hours in 30.4\%, $10.1 \%$, and $1.4 \%$, respectively. Formal briefing packets were distributed to P\&T committee attendees in $85.5 \%$ of the respondents' institutions. Other preparatory processes included use of subcommittees (50.7\%), individual meetings between members and the P\&T committee chair (46.4\%), and informal written correspondence (e.g., email) among attendees (43.5\%).

\section{Training of Contributors to P\&T Committees}

Among all respondents, the most frequently reported source of training in literature evaluation and formulary management was

\begin{tabular}{|c|c|c|}
\hline Source ${ }^{a}$ & $\begin{array}{c}\text { Literature } \\
\text { Evaluation } \\
\text { n (\%) }\end{array}$ & $\begin{array}{c}\text { Formulary } \\
\text { Management } \\
\text { n (\%) }\end{array}$ \\
\hline On-the-job training & $50(72.5)$ & $62 \quad(89.9)$ \\
\hline Professional school curriculum & $45 \quad(65.2)$ & $33(47.8)$ \\
\hline Postgraduate training (general) & $37 \quad(53.6)$ & $23(33.3)$ \\
\hline Postgraduate training (specialized) & $15 \quad(21.7)$ & $12 \quad(17.4)$ \\
\hline Certificate program & $5 \quad(7.2)$ & $2 \quad(2.9)$ \\
\hline None & $1 \quad(1.4)$ & - \\
\hline Other & $1 \quad(1.4)$ & - \\
\hline
\end{tabular}

on-the-job training $(72.5 \%$ and $89.9 \%$, respectively; Table 3$)$. Only $21.7 \%$ received specialized postgraduate training related to literature evaluation (e.g., drug information residency), and only $7.2 \%$ completed certificate programs on this topic. Similarly for formulary management, $17.4 \%$ of respondents received specialized postgraduate training, and $2.9 \% \mathrm{com}-$ pleted certificate programs on this topic.

\section{Satisfaction with Processes and Training of P\&T Committees} Overall, $82.6 \%$ of respondents had favorable views ("agree" or "strongly agree") of their organizations' number of P\&T committee contributors for the preparation and review of P\&T committee documents (Table 4). Similarly, $76.8 \%$ of respondents favorably viewed the training of P\&T committee contributors, and $69.5 \%$ favorably viewed the amount of time available to P\&T committee contributors to author and review P\&T committee documents. A majority of respondents (62.3\%) felt that their formulary evaluation process was at least slightly better than their peers.

Table 5 illustrates the mean rank positions for potential factors considered most beneficial in improving the processes of P\&T committees ( $1=$ most beneficial to $10=$ least beneficial). Guidelines on the authoring and reviewing of P\&T committee documents were considered the most beneficial resource that could improve the functions of P\&T committees (mean rank score: 4.04 out of 10). Other options written in as "other" responses included ad hoc committees, better committee collaboration, shorter and less frequent meetings, and restructuring of the P\&T committee organization.

\section{Discussion}

To our knowledge, this survey study represents the first systematic evaluation of training, responsibilities, and practices of health care professionals who serve on P\&T committees. The results of this study provide initial insight on the current 


\begin{tabular}{|c|c|c|}
\hline \multicolumn{3}{|c|}{$\begin{array}{l}\text { TABLE } 4 \text { Satisfaction with Training and Resources } \\
\text { of P\&T Committee Contributors ( } N=69)\end{array}$} \\
\hline \multicolumn{2}{|l|}{ Criteria } & n (\%) \\
\hline \multirow{5}{*}{$\begin{array}{l}\text { My organization has } \\
\text { an adequate number of } \\
\text { contributors to author and } \\
\text { review P\&T committee } \\
\text { documents. }\end{array}$} & Strongly agree & $23(33.3)$ \\
\hline & Agree & $34 \quad(49.3)$ \\
\hline & Neither agree nor disagree & $7(10.1)$ \\
\hline & Disagree & $4 \quad(5.8)$ \\
\hline & Strongly disagree & (1.4) \\
\hline \multirow{5}{*}{$\begin{array}{l}\text { The training of } \\
\text { contributors to P\&T } \\
\text { committee documents is } \\
\text { adequate. }\end{array}$} & Strongly agree & $19 \quad(27.5)$ \\
\hline & Agree & $34 \quad(49.3)$ \\
\hline & Neither agree nor disagree & $10(14.5)$ \\
\hline & Disagree & $5 \quad(7.2)$ \\
\hline & Strongly disagree & $(1.4)$ \\
\hline \multirow{5}{*}{$\begin{array}{l}\text { The time that contributors } \\
\text { to the } P \& T \text { committee } \\
\text { have is adequate. }\end{array}$} & Strongly agree & $17 \quad(24.6)$ \\
\hline & Agree & $31 \quad(44.9)$ \\
\hline & Neither agree nor disagree & $12 \quad(17.4)$ \\
\hline & Disagree & $8 \quad(11.6)$ \\
\hline & Strongly disagree & $1 \quad(1.4)$ \\
\hline \multirow{6}{*}{$\begin{array}{l}\text { What is your perception of } \\
\text { your organization's overall } \\
\text { formulary evaluation } \\
\text { process compared with } \\
\text { similar organizations? }\end{array}$} & Much better than my peers & $21 \quad(30.4)$ \\
\hline & Slightly better than my peers & $22(31.9)$ \\
\hline & Equal to my peers & $18(26.1)$ \\
\hline & Slightly worse than my peers & $1 \quad(1.4)$ \\
\hline & Much worse than my peers & $(2.9)$ \\
\hline & I have no means to compare & $(7.2)$ \\
\hline
\end{tabular}

training and responsibilities of P\&T committee members and contributors in various health care delivery models.

Results of the survey highlight the opportunity for improvement based on several disconnects between ideals proposed in position statements and what is achieved in practice. For example, respondents stated that literature evaluation skills were most frequently the primary factor that influenced selection of authors for $P \& T$ committee documents, and respondents generally had a favorable view of the training of contributors to P\&T committees at their institutions. However, only $21.7 \%$ of respondents, who often authored P\&T committee documents, received specialized postgraduate training on literature evaluation. Although roughly $72.5 \%$ of respondents received on-the-job training for literature evaluation, this conflicts with the Delfini Group recommendation that training be provided upon initiation of P\&T committee duties, as well as periodically thereafter for all P\&T committee members. Furthermore, the variability in respondents' practice settings could lead to inconsistencies in the nature of on-the-job training and measurement of competencies achieved from such training. The nature of on-the-job training for contributors could be a focus of further research.

Use of informational resources appears spread among various options, with most authors consulting primary literature (89.5\%; Table 2). While the use of primary literature is high, evaluation of primary clinical trials should be carried out for

\section{TABLE 5 Mean Ranking of Potentially Beneficial Resources to Improve P\&T Committee Functions $^{\mathrm{a}}$}

\begin{tabular}{l|c}
\hline $\begin{array}{l}\text { Guidelines on authoring and reviewing documents used by } \\
\text { P\&T committee }\end{array}$ & 4.04 \\
\hline Additional time & 4.09 \\
\hline Additional staff & 4.32 \\
\hline $\begin{array}{l}\text { Consolidated resources for preparation of members of } \\
\text { P\&T committee }\end{array}$ & 4.46 \\
\hline Customizable standard evaluation template & 4.90 \\
\hline Training on the formulary management process & 4.91 \\
\hline Training on authoring drug monographs and class reviews & 5.24 \\
\hline Additional funding for access to resources & 5.94 \\
\hline $\begin{array}{l}\text { Outsourcing P\&T committee evaluations to unbiased } \\
\text { external groups }\end{array}$ & 7.46 \\
\hline Other & 9.40 \\
\hline
\end{tabular}

a Participants ranked potential resources from 1 (most preferred) to 10 (least preferred). Mean ranks were calculated to avoid ties produced from calculating medians.

$P E T=$ pharmacy and therapeutics.

all P\&T committee documents, given that primary literature is the most thorough, original, and up-to-date data that can be evaluated for validity and generalizability. ${ }^{13}$ Other resources were used less frequently, which may explain the lack of access to at least 2 desired resources reported by $44.7 \%$ of respondents. This may be a result of financial limitations in procuring subscription-based information resources. Efforts should be made to improve access to, and evaluation of, reputable informational resources.

Practices for document preparation and execution of P\&T committee meetings also diverged from recommendations. Some respondents (5.8\%) indicated that their committees had no formalized procedure for preparation of committee documents, which conflicts with ASHP recommendations that documents should be consistent from medication to medication. ${ }^{1}$ In addition, $85.5 \%$ of respondents distributed briefing packets before P\&T committee meetings, while recommendations suggest that independent reviews of evidence should be provided to P\&T committees in written documents with a standard format. The use of subcommittees, which is an optional strategy recommended by the ASHP, was only reported by $50.7 \%$ of respondents. While various factors may influence the establishment of P\&T subcommittees, positive effects have been described in various areas, including use of antimicrobial and analgesic medications. ${ }^{14-24}$ It is notable that although a majority of respondents practiced in settings of higher patient load, which may indicate more complicated formulary management, approximately half used subcommittees to address specific therapeutic areas. Further evaluation of potential obstacles to implementing subcommittees and outcomes of their use, or settings in which they are most valuable, are warranted. 
Pharmacists were the most common authors of P\&T committee documents. Frequently, authors were not formal P\&T committee members but were nonmember contributors, suggesting that appointed members may not be the most qualified authors or that other professional responsibilities preclude their service as authors. Almost half of the respondents' institutions outsourced document production to an outside entity. Future research should explore the reasons for which institutions seek outside help in order to address potential limitations in their internal processes.

Respondents believed that guidelines for authoring P\&T committee documents were the most helpful component that could improve their P\&T committee processes. This belief appears to highlight a shortcoming in available guidance for P\&T committee members and contributors upon which to rely when creating effective committee documents.

\section{Limitations}

This study has some limitations to consider. A limitation of the survey was its relatively poor response rate. The small number of respondents within each of the different health care delivery models precluded the exploration of potential associations between practice setting and training and responsibilities. However, the overall respondent sample size is similar to that of a previous national survey of institutions' formulary management processes (52 respondents) and provide an important initial perspective on the practice domains assessed in our survey. ${ }^{25}$ In addition, respondents were predominantly pharmacists (94.2\%), which may be related to the method of identifying health care professionals who likely participate in P\&T committee tasks. Despite their majority representation, pharmacists were the health care professionals most often reported to be authors of P\&T committee documents; therefore, the training and responsibilities reported could be considered reflective of P\&T committee members and contributors who typically provide formulary decision support. Nonetheless, inclusion of nonpharmacist committee members and contributors could illustrate important differences in training, responsibilities, and practice that differ by health care discipline.

\section{Conclusions}

The survey of P\&T committee members and nonmember contributors used in this study identified current training, responsibilities, and practices that can inform recommendations for standard requirements in these domains. Findings suggest that opportunities exist to improve achievement of recommendations to ensure a consistent and universal level of training and application of evidence-based decision making in P\&T committees. Further study of obstacles to these goals should be explored, and standard training of P\&T committee members and nonmember contributors should be considered.

\section{Authors}

RYAN RODRIGUEZ, PharmD, BCPS, and MARY MOODY, BSPharm, University of Illinois at Chicago College of Pharmacy, Chicago, Illinois; BRETT J. KELLY, BSPharm, MS, Global Account Management Group, Waunakee, Wisconsin.

AUTHOR CORRESPONDENCE: Brett J. Kelly, BSPharm, MS, Assistant Professor, Division of Pharmacy Professional Development, University of Wisconsin School of Pharmacy, Madison, WI 53705. Tel.: 608.890.1886; E-mail: brett.kelly@wisc.edu.

\section{DISCLOSURES}

No outside funding supported this study. At the time of this study, Kelly was employed by Global Account Management Group (GAMG), which provides consulting services to the hospital and health services industry. As an employee of GAMG, Kelly has served on various advisory boards. All fees for consulting work were paid to GAMG and were primarily related to training or the federal market (e.g., Department of Defense or the Department of Veterans Affairs) and have no association with this study. Rodriguez and Moody report no conflicts of interest.

All authors contributed to study concept and design. Rodriguez took the lead in data collection, assisted by the other authors. Data interpretation was performed by Rodriguez, along with Kelly and Moody. The manuscript was written and revised primarily by Rodriguez, along with the other authors.

\section{ACKNOWLEDGMENTS}

The authors thank the following individuals for their review of and feedback on the survey instrument: Angela Allerman, PharmD, BCPS, with the Defense Health Agency, Pharmacy Operations Division-South, Formulary Management Branch, Washington, DC, and Masoomeh Khamesian, PharmD, MBA, with Howard County General Hospital, Johns Hopkins School of Medicine, Columbia, Maryland (at the time of this study).

\section{REFERENCES}

1. Tyler LS, Cole SW, May JR, et al. ASHP guidelines on the pharmacy and therapeutics committee and the formulary system. Am J Health Syst Pharm. 2008;65(13):1272-83

2. American Society of Health-System Pharmacists. ASHP statement on the pharmacy and therapeutics committee and the formulary system. Am J Health Syst Pharm. 2008;65(24):2384-86.

3. American Academy of Family Physicians. Patient-centered formularies. Available at: http://www.aafp.org/about/policies/all/patient-formularies.html. Accessed June 3, 2017.

4. American Medical Association. Managed care cost containment involving prescription drugs. Policy H-285.965. 2014. Available at: https://policysearch. ama-assn.org/policyfinder/detail/Managed\%20Care\%20Cost\%20Containment \%20Involving\%20Prescription\%20Drugs\%20H-285.965?uri=\%2FAMADoc\% 2FHOD.xml-0-2089.xml. Accessed June 27, 2017.

5. American Medical Association. Drug formularies and therapeutic interchange. Policy H-125.991. 2010. Available at: https://policysearch.ama-assn. org/policyfinder/detail/Drug\%20Formularies\%20and\%20Therapeutic\%20 Interchange\%20H-125.991?uri=\%2FAMADoc\%2FHOD.xml-0-227.xml. Accessed June 27, 2017.

6. American Society of of Health-System Pharmacists. Principles of a sound drug formulary system. June 4, 2000. Available at: https://www.ashp.org/-/ media/assets/policy-guidelines/docs/endorsed-documents-principles-sounddrug-formulary-system.ashx?la=en. Accessed June 27, 2017. 
7. Centers for Medicare \& Medicaid Services. Medicare Prescription Drug Benefit Manual. Chapter 6 - Part D drugs and formulary requirements. Updated February 19, 2010. Available at: Centers for Medicare and Medicaid Services website. https://www.cms.gov/Medicare/Prescription-DrugCoverage/PrescriptionDrugCovContra/downloads/chapter6.pdf. Accessed June 3, 2017.

8. Stuart ME, Strite SA. Tips for working with an evidence-based review staff. In: Delfini Group, Stuart ME, Strite SA. The Pharmacy \& Therapeutics Committee Evidence-Based Decision-Making Handbook. Delfini Group Publishing; 2015:67-70.

9. Schiff GD, Galanter WL, Duhig J, et al. A prescription for improving drug formulary decision making. PLoS Med. 2012;9(5):1-7.

10. Stuart ME, Strite SA. Skills + resources. In: Delfini Group, Stuart ME, Strite SA. The Pharmacy \& Therapeutics Committee Evidence-Based DecisionMaking Handbook. Delfini Group Publishing; 2015:35-46.

11. Stuart ME, Strite SA. The P\&T committee: members and management. In: Delfini Group, Stuart ME, Strite SA. The Pharmacy \& Therapeutics Committee Evidence-Based Decision-Making Handbook. Delfini Group Publishing; 2015:105-110.

12. Best hospitals: rankings and advice. U.S. News \& World Report. February 19, 2016. Available at: http://health.usnews.com/best-hospitals. Accessed June 3, 2017.

13. Shields KM, Blythe E. Drug information resources. In: Malone PM, Kier KL, Stanovich JE, Malone MJ, eds. Drug Information: A Guide for Pharmacists. 5th ed. New York: McGraw-Hill; 2013.

14. Carlson JA. Antimicrobial formulary management: meeting the challenge in a health maintenance organization. Pharmacotherapy. 1991;11(1 Pt 2):32s-35s.

15. Dunn JD, Cannon HE, Lewis T, Shane-McWhorter L. Development of a complementary and alternative medicine (CAM) pharmacy and therapeutics (P\&T) subcommittee and CAM guide for providers. J Manag Care Pharm. 2005;11(3):252-58. Available at: http://www.jmcp.org/doi/10.18553/ jmcp. 2005.11.3.252.
16. Kimelblatt BJ, Young SH, Heywood PM, Mandala AR, Gendelman S, Mehl B. Improved reporting of adverse drug reactions. Am J Hosp Pharm. 1988;45(5):1086-89.

17. Lewis RP, Moore TD. Achieving an effective committee through reorganization: the Ohio State University Hospital's experience. Hosp Formul. 1991;26(2):120-30.

18. Martin C, Ofotokun I, Rapp R, et al. Results of an antimicrobial control program at a university hospital. Am J Health Syst Pharm. 2005;62(7):732-38.

19. Maswoswe JJ, Okpara AU. Enforcing a policy for restricting antimicrobial drug use. Am J Health Syst Pharm. 1995;52(13):1433-35.

20. McKenna TR, Branigan TA, Sorocki AH. Pharmacy-initiated introduction of patient-controlled analgesia to a 400-bed community hospital. Am J Hosp Pharm. 1989;46(2):291-94.

21. Michael KA, Jozefczyk KG, Nelson RP, Linn P, Fogle P, Wise J. A multidisciplinary approach to patient controlled analgesia. Hosp Pharm 1989;24(10):829-34.

22. Record KE, Dickens GR, Amerson AB, Rapp RP. Implementation of a criteria-based antimicrobial formulary system. Am J Health Syst Pharm. 1995;52(6 Suppl 2):S34-38

23. Sloan NE, Peroutka JA, Morgan DE, Ross MB, Mutnick AH. Influencing prescribing practices and associated outcomes utilizing the drug use evaluation process. Top Hosp Pharm Manage. 1994;14(3):1-12.

24. Taylor G, Blondel-Hill E, Kibsey P, Friesen E, Tisdell R, Vaudry W. Containing cefoxitin costs through a program to curtail use in surgical prophylaxis. Can J Infect Dis. 1993;4(5):275-78.

25. Anagnostis E, Wordell C, Guharoy R, Beckett R, Price V. A national survey on hospital formulary management processes. J Pharm Pract. 2011;24(4):409-16. 